Fernando C Barros ${ }^{1}$

Aluísio J D Barros"

José Villar'II

\section{Alicia Matijasevich"}

Marlos R Domingues ${ }^{\text {IV }}$

Cesar G Victora"

Programa de Pós-Graduação em Saúde e Comportamento. Universidade Católica de Pelotas. Pelotas, RS, Brasil

" Departamento de Medicina Social. Programa de Pós-Graduação em Epidemiologia. Universidade Federal de Pelotas (UFPel). Pelotas, RS, Brasil

III Nuffield Department of Obstetrics and Gynaecology. University of Oxford. Oxford, United Kingdom

Iv Departamento de Desportos. Programa de Pós-Graduação em Educação Física. UFPel. Pelotas, RS, Brasil

Correspondence:

Fernando C. Barros

Universidade Católica de Pelotas

R. Marechal Deodoro, 1160 - $3^{\circ}$ piso

Centro

96020-220 Pelotas, RS, Brasil

E-mail: fcbarros.epi@gmail.com

\section{How many low birthweight babies in low- and middle- income countries are preterm?}

\section{Quantos dos recém-nascidos de baixo peso de países emergentes são pré-termo?}

\begin{abstract}
OBJECTIVE: To assess the prevalence of preterm birth among low birthweight babies in low and middle-income countries.

METHODS: Major databases (PubMed, LILACS, Google Scholar) were searched for studies on the prevalence of term and preterm LBW babies with field work carried out after 1990 in low- and middle-income countries. Regression methods were used to model this proportion according to LBW prevalence levels.
\end{abstract}

RESULTS: According to 47 studies from 27 low- and middle-income countries, approximately half of all LBW babies are preterm rather than one in three as assumed in studies previous to the 1990s.

CONCLUSIONS: The estimate of a substantially higher number of LBW preterm babies has important policy implications in view of special health care needs of these infants. As for earlier projections, our findings are limited by the relative lack of population-based studies.

DESCRIPTORS: Infant, Low Birth Weight. Infant, Premature. Developing Countries. Review. 


\section{RESUMO}

OBJETIVO: Estimar a prevalência de recém-nascidos pré-termo entre os recém-nascidos de baixo peso ao nascer de países de renda média ou baixa.

MÉTODOS: Em consulta a bases de dados (PubMed, LILACS, Google Scholar) foram procurados estudos sobre a prevalência de recém-nascidos a termo e prétermo entre aqueles de baixo peso ao nascer conduzidos após 1990 em países emergentes. Modelos de regressão foram usados para avaliar a proporção de acordo com as prevalências de baixo peso.

RESULTADOS: Com base em 47 estudos de 27 países emergentes, aproximadamente metade de todos os recém-nascidos com baixo peso seriam prematuros, em vez de um a cada três, como estimado em estudos anteriores à década de 1990 .

CONCLUSÕES: A estimativa de números substancialmente mais altos de prematuros com baixo peso tem importantes reflexos no planejamento em saúde, uma vez que esses recém-nascidos demandam cuidados especiais. Todavia, os achados são limitados pela falta de estudos populacionais.

\section{DESCRITORES: Recém-Nascido de Baixo Peso. Prematuro. Países em Desenvolvimento. Revisão.}

\section{INTRODUCTION}

Preterm babies account for $27 \%$ of nearly 4 million neonatal deaths worldwide every year. ${ }^{31}$ Those preterm babies weighing less than $2500 \mathrm{~g}$ are more likely to die. Infant mortality rate among preterm low birthweight (LBW) babies is five times higher than that of preterm babies weighing $2500 \mathrm{~g}$ or more, ${ }^{48}$ and that of term LBW babies.$^{68}$ The latter group comprises mostly babies with intra-uterine growth restriction (IUGR). ${ }^{30}$ Because of this much higher mortality, it is important to estimate how many LBW babies are preterm as they require special health care.

In low- and middle-income countries (LMICs), where most infant deaths occur, nearly half of all births take place at home without skilled care, ${ }^{57}$ and newborn babies are neither weighted nor have their gestational age assessed. The United Nations Children's Fund (UNICEF) and the World Health Organization (WHO) have produced country-level LBW estimates using data from health statistics and surveys. ${ }^{56}$ In relation to gestational age distribution, regional estimates of the overall proportion of preterm births were recently published. ${ }^{8}$

The prevalence and number of LBW babies born who have either IUGR or are preterm in developing countries have been recently estimated by scientists of different institutions as part of the Maternal and Child Nutrition Study Group..$^{10}$ They have estimated that more than two-thirds of LBW babies born in the developing world have IUGR, and the remaining one third is preterm. These estimates used a predictive equation derived from hospital studies carried out between 1964 and $1990 .{ }^{9,13,59,62}$
There are reasons for questioning whether the equation derived from pre-1990 studies is still valid in the light of global changes in LBW and preterm prevalence. UNICEF reported a reduction in LBW prevalence - from $18 \%$ in $1990-1994$ to $16 \%$ in $1996-2006$ - in all LMICs, and from $23 \%$ to $17 \%$, respectively, in the least developed countries. ${ }^{55,57}$ In addition, selected studies indicate a decreasing prevalence of IUGR in some $\mathrm{LMICs}^{2,7,33}$ at the same time that others report substantial increases in preterm births. ${ }^{722,27,49}$ Data from South America suggest that the proportion of preterm LBW babies has increased among LBW births from 59\% (1992) to 70\% (2000) in Uruguay (PAHO/WHO Latin American Center for Perinatology, unpublished observations) and from $46 \%$ (1996) to 62\% (2004) in Brazil. ${ }^{47}$ The latter trend is confirmed in Brazilian birth cohort studies in the city of Pelotas, Southern Brazil, where this proportion increased from $60 \%$ in 1993 to $68 \%$ in 2004.7

In view of recent changes - in opposite directions - in the prevalence of preterm and term LBW babies, we decided to generate a new set of predictive equations using data obtained from post-1990 studies. Therefore, the aim of this study was to assess the prevalence of preterm birth among low birthweight babies in low and middle-income countries.

\section{METHODS}

We reviewed major databases (PubMed, LILACS, Google Scholar) for studies on the prevalence of term and preterm LBW babies with field work carried 
out after 1990 in countries classified by the World Bank as LMICs. ${ }^{a}$ Keywords used in the review were preterm births, low birth weight, and low and middleincome countries. The authors were contacted in many instances to provide further information. We also searched websites of the ministries of health in countries mostly in Latin America where this information is available. Although the best was to work with national estimates, they were rarely available and we had to rely on subnational samples. Further information was obtained from randomized trials, either from baseline or endline assessments (the latter was included only when there was no effect of the intervention).

Studies were included only if birthweight was obtained through weighing, but not by surrogates such as reported size of the baby at birth or chest circumference measures, and when estimates of gestational age were based on at least one of the following methods: last menstrual period, ultrasound before 20 weeks, or physical examination (Dubowitz, ${ }^{15}$ Ballard, ${ }^{5}$ Capurro ${ }^{11}$ and Finnstrom ${ }^{19}$ methods). Only live births were included. Low birthweight was defined as less than $2500 \mathrm{~g}$, and preterm birth was defined as less than 37 completed weeks of gestation. All studies were conducted after 1990 with the exception of a long-term community study in Gambia over 1976-2003. LMICs were divided by region according to UNICEF classification. ${ }^{57}$

Linear regression and Pearson's correlation coefficients were used to compare our set of post-1990 studies with previous studies. ${ }^{62,59}$ The best predictive equations for estimating preterm LBW from overall LBW prevalence were selected using linear regression, polynomial linear regression and nonlinear models; the latter two were used to account for non-linearity in the relationship between the outcome and low birthweight prevalence. The polynomial regression tested up to the cubic terms. We also assessed non-linear models based on exponential, Gompertz and logistic functions. The models were compared in terms of goodness of fit (Akaike Information Criterion, AIC) and biological plausibility. The non-linear model chosen was:

$\mathrm{Y}=\beta_{1} /\left(1+\exp \left(-\beta_{2} \times\left(\mathrm{X}-\beta_{3}\right)\right)\right)$.

The standard error for the predictions was obtained through the following expression:

s.e. $($ prediction $)=[\operatorname{var}(\text { Y-hat })+\operatorname{var}(\text { residual })]^{1 / 2}$,

where Y-hat is the fitted value. Confidence intervals were obtained by the expression

Y-hat $\pm 1.96 \times$ s.e.(prediction)

All regression models were weighted by sample size and adjusted for clustering at country level as several countries had more than one data source.
To assess whether the results of community-based and facility-based studies presented in the Results section below were statistically different, we used a generalized linear model with region as a fixed factor and type of study as a random factor, with the outcome prevalence as the dependent variable.

\section{RESULTS}

Data from 47 studies from 27 LMICs were studied. The Table shows for each study site: country and year of study, method of gestational age assessment, type of study, sample size, and prevalence of LBW, preterm LBW and term LBW. Whenever available, the prevalences of preterm births and preterm babies weighing $2500 \mathrm{~g}$ or more were also presented. There were 15 studies from eight Sub-Saharan African countries, 12 studies from four South Asian countries, 10 studies from eight Latin American and Caribbean countries, four studies from three countries in the East Asia and Pacific, four studies from three countries in the Middle East and North Africa, and two studies from Turkey (Central and Eastern Europe and the Commonwealth of Independent States - CEE/CIS region).

Regarding the type of study, 33 were facility-based (prenatal clinics or maternity hospitals), 13 were community-based, and only one was nationwide. Among 12 South Asian study sites, seven were facilitybased and five community-based. In Sub-Saharan Africa, only two of 15 studies were community-based, the remaining were all facility-based; and four studies in this region were primarily related to malaria. In Latin America and Caribbean, one was a national study (Argentina), three covered all maternity hospitals in defined geographical areas where home births are very rare, and six were based on a single hospital.

In 19 study sites, gestational age was evaluated by the use of the last menstrual period (LMP) alone, 20 combined LMP with physical examination and/or ultrasound, and eight used only physical examination methods.

Based on this initial comparison of studies, South Asian sites presented the highest prevalence of both term LBW (unweighted mean of 21.8\%) and preterm LBW (10.6\%) babies. Compared to South Asia, Sub-Saharan African sites had fewer term LBW and preterm LBW babies with mean prevalence of $7.1 \%$ and $6.5 \%$, respectively. Preterm LBW mean prevalence in Latin America/Caribbean, Middle East/North Africa, CEE/ CIS and East Asia/Pacific studies were 6.1\%, 3.0\%, $4.9 \%$ and $3.9 \%$, respectively. As mentioned before, most studies were facility- or community-based, and therefore not representative of the country as a whole, as this type of study is rarely available.

${ }^{a}$ World Bank. How we classify countries. [cited 2008 Nov 15]. Available from: http://data.worldbank.org/about/country-classifications 


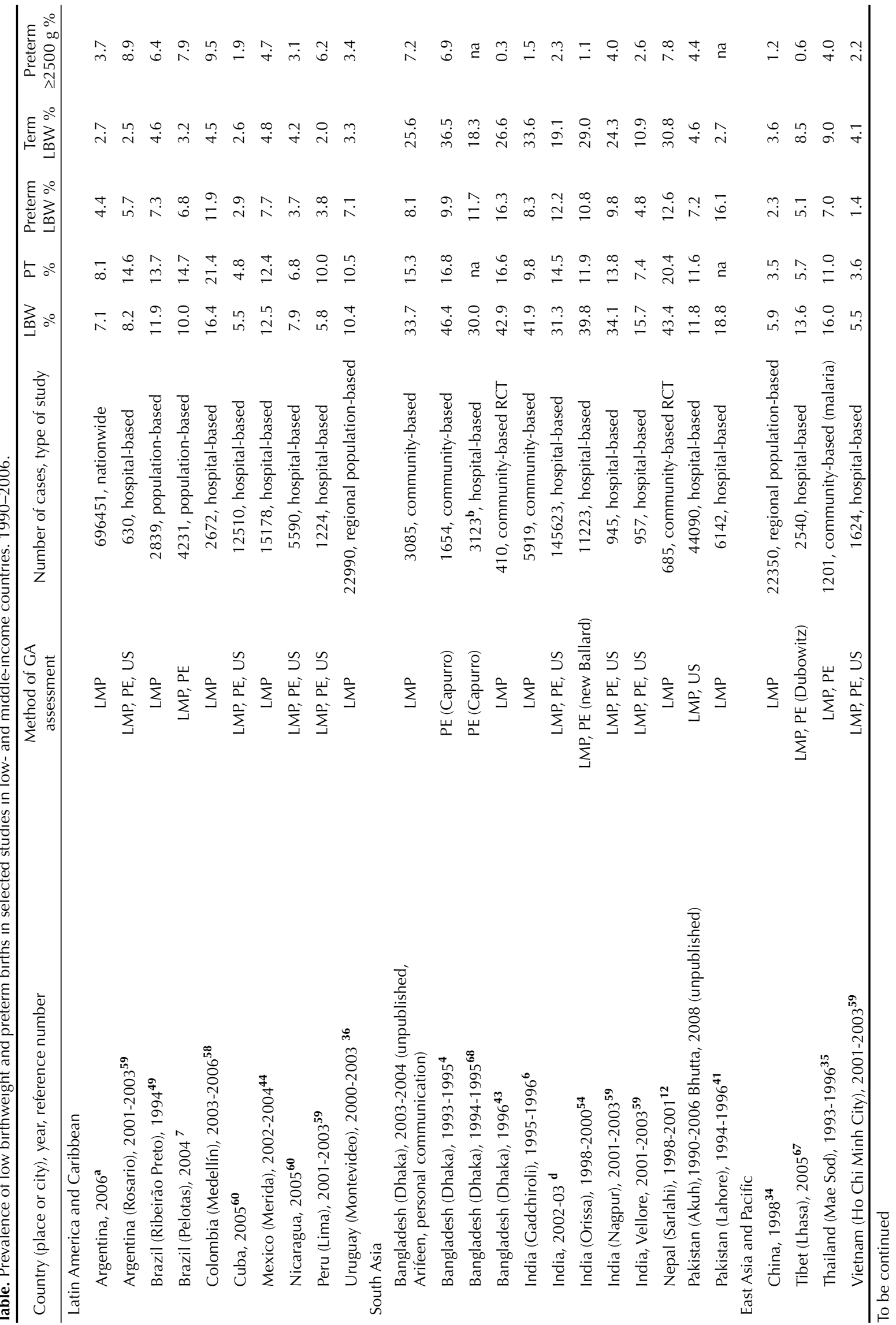




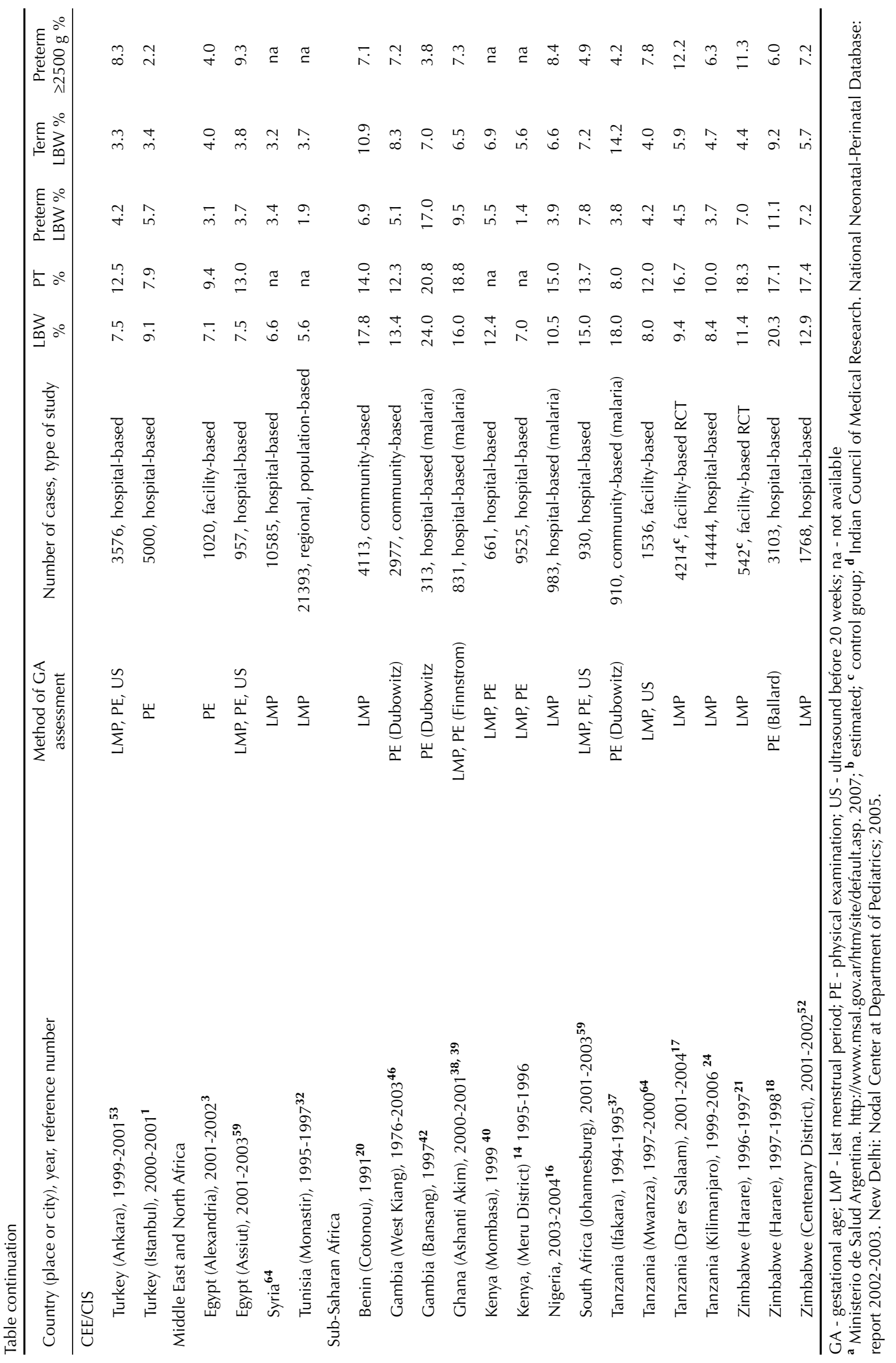


Community-based and hospital-based sites in Latin America/Caribbean showed similar prevalence rates of LBW, preterm LBW and term LBW. In South Asian sites, however, the mean prevalence of LBW and term LBW was much higher in community-based $(41.6 \%$ and $30.6 \%)$ than in hospital-based studies $(25.9 \%$ and $15.6 \%$, respectively). For Sub-Saharan Africa, there were no significant differences in LBW and preterm LBW prevalences between the two community-based and 13 hospital-based studies, but term LBW babies were more prevalent in community-based than in hospital-based studies (mean prevalence of $11.2 \%$ and $6.5 \%$, respectively; $\mathrm{p}=0.013$ ).

On the other hand, the prevalence of LBW was slightly higher in the four studies primarily related to malaria in Sub-Saharan Africa (17.1\%) compared to other nonmalaria studies (12.4\%), although the difference was not statistically significant $(\mathrm{p}=0.095)$.

First we regressed the prevalence of preterm LBW on overall LBW prevalence in the 47 sites using a comparable approach to that of earlier publications that serve as a basis for current global estimates - linear regression unweighted for cluster or sample size. Figure 1 shows the regression lines from the analyses conducted in $1982,{ }^{62} 1994^{59}$ and our current estimates, suggesting that the contribution of preterm LBW to LBW population has increased over time. Likewise, the correlation coefficients between preterm LBW and overall LBW prevalence increased from $0.08(\mathrm{p}>0.05)$ in the 1982 analyses to $0.59(\mathrm{p}<0.001)$ in 1994 , and finally to 0.72 $(\mathrm{p}<0.001)$ in the current data.

Several candidate models were assessed to describe the relationship between preterm LBW and LBW prevalence, i.e., polynomial linear and nonlinear models. Simple linear models were not good-fitting ones $(\mathrm{AIC}=155.8)$. Quadratic linear regression provided a good fit $(\mathrm{AIC}=119.2)$, but yielded an implausible

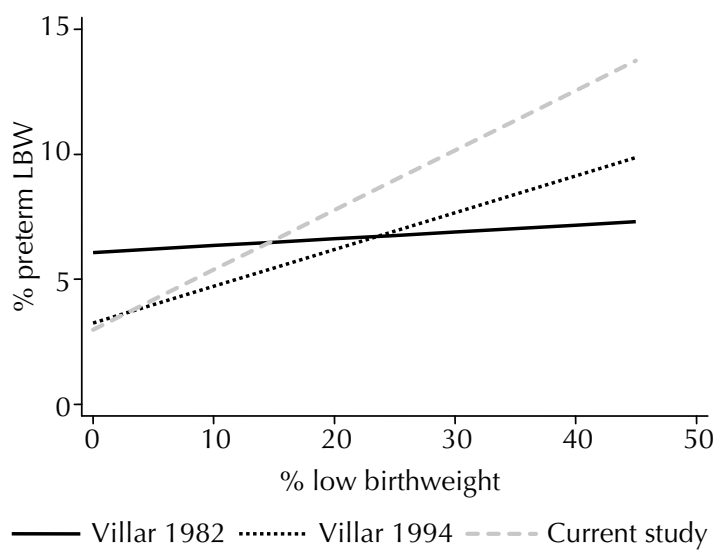

Figure 1. Regression lines of preterm LBW by LBW in LMICs for studies by Villar $1982(n=25)$, Villar $1994(n=60)$, and current data $(n=47)$. model where the predicted prevalence of preterm LBW decreased after LBW prevalence reached $30 \%$ (as the model fits a parabola). Among the nonlinear models assessed, the one based on the logistic function provided the best fit ( $\mathrm{AIC}=124.6$ ), almost as good as the quadratic model, but without the decreasing prevalence in preterm LBW for high LBW rates. This was the chosen model.

A nonlinear logistic function regression model, weighted by sample size and taking into account the clustering of studies by country, was used to describe how preterm LBW varied according to overall LBW prevalence for the 47 study sites. Figure 2 shows that the prevalence of preterm LBW markedly increases with LBW between $5 \%$ and $20 \%$, slows down between $20 \%$ and $30 \%$, and reaches a plateau of around $12 \%$ when overall LBW prevalence exceeds $30 \%$. It should be noted that all sites with LBW higher than $30 \%$ were in South Asia. The predictive equation was a 3-parameter logistic function as follows:

Preterm LBW $=$ b1/(1+exp(-b2*(LBW - b3) $))$

where the coefficients are:

$\mathrm{b} 1=11.96$

$\mathrm{b} 2=0.23$

$\mathrm{b} 3=9.72$

\section{DISCUSSION}

Our main finding was that preterm infants account for a larger proportion of all LBW babies than is currently assumed. ${ }^{59,62}$ Previous estimates based on pre-1990 studies suggest that around one third of all LBW babies born in LMICs are preterm and two thirds are term, ${ }^{10,13}$ whereas our analyses suggest that preterm babies account for at least half of all LBW babies. Previous models also assumed a linear relationship between total LBW and preterm LBW, whereas we showed a

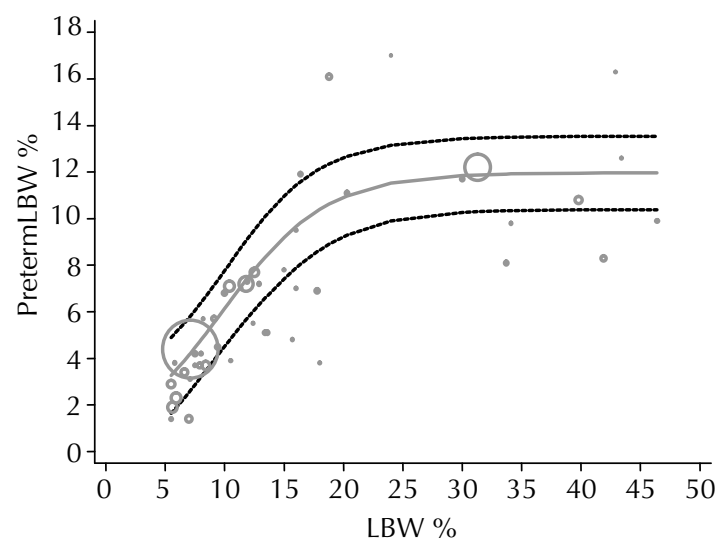

Figure 2. Prevalence of preterm LBW in 47 studies on LBW prevalence in low- and middle-income countries. 
curvilinear association. Whether the differences related to earlier studies represent real time trends - either an increase in preterm babies or a decline in term LBW babies - is unclear.

Our finding of high rates of preterm LBW births in areas where term LBW are also highly prevalent, as in South Asia and Sub-Saharan Africa, is not unexpected. In LMICs, IUGR and preterm delivery share several common determinants such as low body mass index, malaria, smoking, pregnancy-induced hypertension, and pre-eclampsia. ${ }^{25,29,51,65}$ Thus, countries with high prevalence of risk factors (such as low maternal body mass index and malaria) with a resulting high prevalence of term LBW are also more likely to present high rates of preterm LBW births. In addition, a number of studies ${ }^{7,23,28,45,50}$ show that preterm births are more frequent among poor populations. For these reasons, the current findings are more biologically and epidemiologically plausible than those from earlier studies based on data collected pre-1990, which showed little variation of preterm rates across a wide range of LBW prevalences.

When we applied our curvilinear regression model to the national LBW estimates provided by UNICEF, ${ }^{57}$ we estimated that 10.3 million of the 20.3 million LBW born each year in LMICs are preterm, compared to the 6.6 million in the previous estimate. Thus, based on our estimates, 3.7 million babies would shift from the term to the preterm LBW category. ${ }^{10}$ Nevertheless, given the small number of community-based studies available for world regions where home birth delivery is the rule, any predictions of preterm LBW based on LBW must be interpreted with great caution. Also, the confidence intervals presented in Figure 2 points to the need of careful interpretation of estimates.

Our study has limitations. The data was obtained mostly from hospital-based studies, as few community-based studies with information on birthweight and gestational age were available. However, this was also a limitation of earlier studies ${ }^{9,13,59,62}$ that produced the model for the currently used estimates. ${ }^{10}$

In South Asia, the world region with the lowest overall hospital coverage of deliveries $(36 \%),{ }^{57}$ the five community-based studies included in the present review showed considerably higher prevalences of LBW $(41.6 \%)$ than those reported in the seven facilitybased studies (25.9\%). In Sub-Saharan Africa, the two community-based studies showed higher prevalences of term LBW $(11.3 \%)$ than those in the remaining 13 hospital-based studies (6.5\%). One must bear mind these important variabilities when applying the results of our equation to obtain national or regional estimates of preterm LBW.
The datasets ranged in size from a few hundred to over two million births. We were unable to find studies for every country, but included more than one study from the same country when available. Among the 12 South Asian study sites, for example, five were from India, four from Bangladesh, two from Pakistan and one from Nepal. In the 15 Sub-Saharan African studies, there were four from Tanzania and three from Zimbabwe. However, differences in sample sizes and clustering by country were accounted for in the analyses. When the weighted mean regional LBW arising from our analyses was compared with UNICEF regional estimates, the differences were within $10 \%$ except for Middle East/North Africa where UNICEF estimate of $14.9 \%$ is considerably higher than the $6.7 \%$ mean value seen in the studies included in this review. This difference is largely due to the fact that there were no studies from Sudan and Yemen where the estimated LBW prevalence is over $30 \% .{ }^{57}$

A second limitation of this study refers to inconsistent methods for assessing gestational age. Most studies relied on the date of the last menstrual period, alone or combined with physical methods and ultrasound, while in eight sites physical examination was the only method of assessment. It is known that the use of LMP alone overestimates both preterm and post-term rates, ${ }^{26}$ but these same limitations also apply to the previous estimates. ${ }^{10,13}$

Four of the 15 Sub-Saharan African studies were primarily related to malaria, a known cause of both LBW and preterm births. ${ }^{51}$ This is consistent with the present estimates where the mean prevalence of both preterm LBW and term LBW was $8.6 \%$ compared to $5.8 \%$ and $6.6 \%$, respectively, in the other 11 African studies. However, in a region where $80 \%$ of births are in malaria-endemic areas, ${ }^{57,66}$ it does not make sense to exclude these studies from regional estimates.

Low-income countries are unlikely to be able to assess the overall prevalence of LBW preterm infants in the near future, as most births will continue to be at home or in short-staffed health facilities. Our updated equation has considerable advantages over the existing ones that assume a linear relationship. Our model based on post-1990 studies estimates that preterm babies account for at least half of all low birthweight babies in LMICs. This finding that preterm infants account for a higher proportion of those with LBW than currently believed has implications for planning health interventions for this infant population, including skilled providers, incubators, and medicines.

\section{ACKNOWLEDGEMENT}

We thank all colleagues who kindly provided additional information about their studies. 


\section{REFERENCES}

1. Altuncu E, Kavuncuoglu S, Gökmirza PO, Albayrak Z, Arduç A. The incidence of low birth weight in 5000 infants and the etiology of fetal risk factors. Marmara Med J. 2006;19(2):46-51.

2. Antonisamy B, Sivaram M, Richard J, Rao PSS. Trends in intra-uterine growth of single live births in southern India. J Trop Pediatr. 1996;42(6):339-41.

3. Arafa MA, Alkhouly A, Youssef ME. Influence of inter-pregnancy interval on preterm delivery. Paediatr Perinat Epidemiol. 2004;18(4):248-52. DOI:10.1111/ j.1365-3016.2004.00564.x

4. Arifeen SE, Black RE, Caulfield LE, Antelman G, Baqui $\mathrm{AH}, \mathrm{Nahar} \mathrm{Q}$, et al. Infant growth patterns in the slums of Dhaka in relation to birth weight, intrauterine growth retardation, and prematurity. Am J Clin Nutr. 2000;72(4):1010-7.

5. Ballard JL, Khoury JC, Wedig K, Wang L, EilersWalsman BL, Lipp R. New Ballard Score, expanded to include extremely premature infants. J Pediatr. 1991;119(3):417-23.

6. Bang AT, Baitule SB, Reddy HM, Deshmukh MD, Bang RA. Low birth weight and preterm neonates: can they be managed at home by mother and a trained village health worker? J Perinatol. 2005;25 (Suppl 1):S72-81. DOI:10.1038/sj.jp.7211276

7. Barros FC, Victora CG, Matijasevich A, Santos IS, Horta BL, Silveira MF, et al. Preterm births, low birth weight, and intrauterine growth restriction in three birth cohorts in Southern Brazil: 1982, 1993 and 2004. Cad Saude Publica. 2008;24 (Suppl 3):S390-8. DOI:10.1590/S0102-311X2008001500004

8. Beck S, Wojdyla D, Say L, Betran AP, Merialdi M, Requejo $\mathrm{JH}$, et al. The worldwide incidence of preterm birth: a systematic review of maternal mortality and morbidity. Bull World Health Organ. 2010;88(1):31-8. DOI:10.2471/BLT.08.062554

9. Belizán JM, Lechtig A, Villar J. Distribution of low-birth weight babies in developing countries. Am J Obstet Gynecol. 1978;132(6):704-5.

10. Black RE, Allen LH, Bhutta ZA, Caulfield LE, de Onis M, Ezzati $M$, et al. Maternal and child undernutrition: global and regional exposures and health consequences. Lancet. 2008;371(9608):243-60. DOI:10.1016/S0140-6736(07)61690-0

11. Capurro H, Konichezky S, Fonseca D, Caldeyro-Barcia R. A simplified method for diagnosis of gestational age in the newborn infant. J Pediatr. 1978;93(1):120-2.

12. Christian P, Khatry SK, Katz J, Pradhan EK, LeClerq SC, Shrestha SR, et al. Effects of alternative maternal micronutrient supplements on low birth weight in rural Nepal: double blind randomised community trial. BMI. 2003;326(7389):571. DOI:10.1136/bmj.326.7389.571

13. de Onis M, Blossner M, Villar J. Levels and patterns of intrauterine growth retardation in developing countries. Eur J ClinNutr. 1998;52 (Suppl 1):S5-15.

14. Donzelli G, Rapisardi G, Pratesi S, Tomasini B, Zani S, Balzi D, et al. Low birth weight in a Kenyan rural hospital. Prenat Neonatal Med. 2000;5(4):243-7.
15. Dubowitz LM, Dubowitz V, Goldberg C. Clinical assessment of gestational age in the newborn infant. J Pediatr. 1970;77(1):1-10.

16. Falade CO, Yusuf BO, Fadero FF, Mokuolu OA, Hamer $\mathrm{DH}$, Salako LA. Intermittent preventive treatment with sulphadoxine-pyrimethamine is effective in preventing maternal and placental malaria in Ibadan, south-western Nigeria. Malar J. 2007;6:88. DOI:10.1186/1475-2875-6-88

17. Fawzi MC, Msamanga GI, Urassa W, Hertzmark E, Petraro P, Willet WC, et al. Vitamins and perinatal outcomes among HIV-negative women in Tanzania. N Engl J Med. 2007;356(14):1423-31. DOI:10.1056/ NEJMoa064868

18. Feresu SA, Harlow SD, Welch K, Gillespie BW. Incidence of and socio-demographic risk factors for stillbirth, preterm birth and low birthweight among Zimbabwean women. Paediatr Perinat Epidemiol. 2004;18(2):154-63. DOI:10.1111/j.13653016.2003.00539.x

19. Finnstrom O. Studies on maturity in newborn infants. IX. Further observations on the use of external characteristics in estimating gestational age. Acta Paediatr Scand. 1977;66(5):601-4.

20. Fourn L, Ducic S, Séguin L. Facteurs associés à la naissance des enfants de faible poids: une analyse multivariée. Sante. 1999;9(1):7-11.

21. Friis $\mathrm{H}$, Gomo $\mathrm{E}$, Nyazema $\mathrm{N}$, Ndhlovu $\mathrm{P}$, Krarup $\mathrm{H}$, Kaestel $\mathrm{P}$, et al. Effect of multimicronutrient supplementation on gestational length and birth size: a randomized, placebo-controlled, double-blind effectiveness trial in Zimbabwe. Am J Clin Nutr. 2004;80(1):178-84.

22. Grandi C, Dipierri JE. Tendencia secular del peso de nacimiento en Argentina (1992-2002): un estudio poblacional. Arch Argent Pediatr. 2008;106(3):219-25.

23. Gray R, Bonellie SR, Chalmers J, Greer I, Jarvis S, Williams C. Social inequalities in preterm birth in Scotland 1980-2003: findings from an area-based measure of deprivation. BJOG. 2008;115(1):82-90. DOI:10.1111/j.1471-0528.2007.01582.x

24. Habib NA, Daltveit AK, Bergsjo P, Shao J, Oneko O, Lie RT. Maternal HIV status and pregnancy outcomes in northeastern Tanzania: a registry-based study. BJOG. 2008;115(5):616-24. DOI:10.1111/j.14710528.2008.01672.x

25. Hendler I, Goldenberg RL, Mercer BM, lams JD, Meis PJ, Moawad AH, et al. The Preterm Prediction Study: association between maternal body mass index and spontaneous and indicated preterm birth. Am J Obstet Gynecol. 2005;192(3):882-6. DOI:10.1016/j. ajog.2004.09.021

26. Joseph KS, Huang L, Liu S, Ananth CV, Allen AC, Sauve $\mathrm{R}$, et al. Reconciling the high rates of preterm and postterm birth in the United States. Obstet Gynecol. 2007;109(4):813-22. DOI:10.1097/01. AOG.0000255661.13792.c1

27. Kozlovskaya A, Bojko E, Odland JO, Grjibovski AM. Secular trends in pregnancy outcomes in 1980-1999 in the Komi Republic, Russia. Int J Circumpolar Health. 2007;66(5):437-48. 
28. Kramer MS, Goulet L, Lydon J, Séguin L, McNamara $\mathrm{H}$, Dassa $\mathrm{C}$, et al. Socio-economic disparities in preterm birth: causal pathways and mechanisms. Paediatr Perinat Epidemiol. 2001;15 (Suppl 2):104-23. DOI:10.1046/j.1365-3016.2001.00012.x

29. Kramer MS, Victora CG. Low birth weight and perinatal mortality. In: Semba RD, Bloem MW, editors. Nutrition and health in developing countries. Totowa: Humana Press; 2001. p.57-69.

30. Kramer MS. The epidemiology of adverse pregnancy outcomes: an overview. J Nutr. 2003;133(5 Suppl 2):1592S-6S.

31. Lawn JE, Cousens S, Zupan J. 4 million neonatal deaths: when? Where? Why? Lancet. 2005;365(9462):891-900. DOI:10.1016/S01406736(05)71048-5

32. Letaief M, Soltani MS, Salem KB, Bchir A. Épidémiologie de l'insuffisance pondérale à la naissance dans le Sahel tunisien. Sante Publique. 2001;13(4):359-66. DOI:10.3917/spub.014.0359

33. Li CY, Sung FC. Socio-economic inequalities in low-birth weight, full-term babies from singleton pregnancies in Taiwan. Public Health. 2008;122(3):243-50. DOI:10.1016/j. puhe.2007.05.011

34. Lin L, Liu Y, Zhang X, Mi J, Cao L. Sampling survey on low-birth weight in China in 1998. Zhonghua Yu Fang Yi Xue Za Zhi. 2002;36(3):149-53.

35. Luxemburger C, McGready R, Kham A, Morison L, Cho T, Chongsuphajaisiddhi T, et al. Effects of malaria during pregnancy on infant mortality in an area of low malaria transmission. Am J Epidemiol. 2001;154(5):459-65. DOI:10.1093/aje/154.5.459

36. Matijasevich A, Barros FC, Díaz-Rossello JL, Bergel E, Forteza AC. Factores de riesgo para muy bajo peso al nacer y peso al nacer entre 1.500-2.499g: un estúdio del sector público de Montevideo, Uruguay. Arch Pediatr Urug. 2004;75(1):26-35.

37. Menendez C, Ordi J, Ismail MR, Ventura PJ, Aponte JJ, Kahigwa E, et al. The impact of placental malaria on gestational age and birth weight. J Infect Dis. 2000;181(5):1740-5. DOI:10.1086/315449

38. Mockenhaupt FP, Bedu-Addo G, von Gaertner C, Boyé R, Fricke K, Hannibal I, et al. Detection and clinical manifestation of placental malaria in southern Ghana. Malar J. 2006;5:119. DOI:10.1186/1475-2875-5-119

39. Mockenhaupt FP, Hamann L, von Gaertner C, Bedu-Addo G, von Kleinsorgen C, Schumann $\mathrm{RR}$, et al. Common polymorphisms of toll-like receptors 4 and 9 are associated with the clinical manifestation of malaria during pregnancy. J Infect Dis. 2006;194(2):184-8. DOI:10.1086/505152

40. Mwanyumba F, Inion I, Gaillard P, Mandaliya K, Praet $\mathrm{M}$, Temmerman M. Placental inflammation and perinatal outcome. Eur J Obstet Gynecol Reprod Biol. 2003;108(2):164-70. DOI:10.1016/S03012115(02)00438-4

41. Najmi RS. Distribution of birthweights of hospital born Pakistani infants. J Pak Med Assoc. 2000;50(4):121-4.
42. Okoko BJ, Wesumperuma LH, Ota MO, Pinder $\mathrm{M}$, Banya W, Gomez SF, et al. The influence of placental malaria infection and maternal hypergammaglobulinemia on transplacental transfer of antibodies and IgG subclasses in a rural West African population. J Infect Dis. 2001;184(5):627-32. DOI: $10.1086 / 322808$

43. Osendarp SJ, van Raaij JM, Arifeen SE, Wahed $\mathrm{M}$, Baqui AH, Fuchs GJ. A randomized, placebocontrolled trial of the effect of zinc supplementation during pregnancy on pregnancy outcome in Bangladeshi urban poor. Am J Clin Nutr. 2000;71(1):114-9.

44. Osorno Covarrubias L, Acosta Mass A, Dávila Velasquez J, Rodriguez Chapuz J, Escamilla Sosa M, Echeverria Eguiluz M. Mortalidad neonatal em un hospital perinatal regional de Mérida, Yucatán, de 1995 a 2004. I. Análisis de las tasas crudas y específicas. Ginecol Obstet Mex. 2006;74(8):401-9.

45. Peacock JL, Bland JM, Anderson HR. Preterm delivery: effects of socioeconomic factors, psychological stress, smoking, alcohol, and caffeine. BMJ. 1995;311(7004):531-5.

46. Rayco-Solon P, Fulford AJ, Prentice AM. Differential effects of seasonality on preterm birth and intrauterine growth restriction in rural Africans. Am / Clin Nutr. 2005;81(1):134-9.

47. Rede Interagencial de Informaçao para a Saúde. Indicadores básicos para a saúde no Brasil: conceitos e aplicações. 2. ed.Brasilia, DF: Organização PanAmericana da Saúde; 2008.

48. Santos IS, Menezes AMB, Mota DM, Albernaz EP, Barros AJD, Matijasevich A, et al. Infant mortality in three population-based cohorts in Southern Brazil: trends and differentials. Cad Saude Publica. 2008;24 (Suppl 3):S451-60. DOI:10.1590/S0102311X2008001500011

49. Silva AA, Barbieri MA, Gomes UA, Bettiol H. Trends in low birth weight: a comparison of two birth cohorts separated by a 15-year interval in Ribeirão Preto, Brazil. Bull World Health Organ. 1998;76(1):73-84.

50. Smith LK, Draper ES, Manktelow BN, Dorling JS, Field DJ. Socioeconomic inequalities in very preterm birth rates. Arch Dis Child Fetal Neonatal Ed. 2007;92(1):F11-4. DOI:10.1136/adc.2005.090308

51. Steketee RW Nahlen BL, Parise ME, Menendez C. The burden of malaria in pregnancy in malaria-endemic areas. Am J Trop Med Hyg. 2001;64(1/2 Suppl):28-35.

52. Ticconi C, Arpino C, Longo B, Mapfumo M. Prevalence and risk factors for low birth weight in Northern Zimbabwe. Int J Gynaecol Obstet. 2005;88(2):146-7. DOI:10.1016/j.ijgo.2004.11.018

53. Toygar HU, Seydaoglu G, Kurklu S, Guzeldemir E, Arpak N. Periodontal health and adverse pregnancy outcome in 3,576 Turkish women. J Periodontol. 2007;78(11):2081-94. DOI:10.1902/jop.2007.070092

54. Tripathy R, Parida SN, Tripathy SN, Devi PS, Das RN, Swain A. Physical status of newborns and neonatal outcome. Indian J Pediatr. 2002;69(12):1041-5

55. UNICEF. The state of the world's children 1998: focus on nutrition. New York; 1998 
56. UNICEF. Low birth weight: country, regional and global estimates. New York; 2004.

57. UNICEF. State of the world's children 2008: child survival. New York; 2008.

58. Vélez-Gómez MP, Barros FC, Echavarría-Restrepo LG, Hormaza-Angel MP. Prevalencia de bajo peso al nacer y factores maternos asociados: Unidad de Atención y Protección Materno Infantil de la Clinica Universitaria Bolivariana, Medellin, Colombia. Rev Colomb Obstet Ginecol. 2006;57(4):264-70.

59. Villar J, Belizan JM. The relative contribution of prematurity and fetal growth retardation to low birth weight in developing and developed societies. Am J Obstet Gynecol. 1982;143(7):793-8.

60. Villar J, Ezcurra EG, de La Fuente VG, Canpodonico I. Preterm delivery syndrome: the unmet need. Res Clin Forums. 1994;16:9-33.

61. Villar J, Valladares E, Wojdyla D, Zavaleta N, Carroli G, Velazco A, et al. Caesarean delivery rates and pregnancy outcomes: the 2005 WHO global survey on maternal and perinatal health in Latin America. Lancet. 2006;367(9525):1819-29. DOI:10.1016/S01406736(06)68704-7

62. Villar J, Abdel-Aleem H, Merialdi M, Mathai M, Ali MM, Zavaleta N, et al. World Health Organization randomized trial of calcium supplementation among low calcium intake pregnant women. Am J Obstet
Gynecol. 2006;194(3):639-49. DOI:10.1016/ ajog.2006.01.068.

63. Wannous S, Arous S. Incidence and determinants of low birth weight in Syrian government hospitals. East Mediterr Health J. 2001;7(6):966-74.

64. Watson-Jones D, Weiss HA, Changalucha JM, Todd J, Gumodoka B, Bulmer J, et al. Adverse birth outcomes in United Republic of Tanzania: impact and prevention of maternal risk factors. Bull World Health Organ. 2007;85(1):9-18. DOI:10.1590/S004296862007000100007

65. Wen SW, Goldenberg RL, Cutter GR, Hoffman HJ, Cliver SP. Intrauterine growth retardation and preterm delivery: prenatal risk factors in an indigent population. Am J Obstet Gynecol. 1990;162(1):213-8.

66. World Health Organization. A strategic framework for malaria prevention and control during pregnancy in the African Region. Brazzaville: WHO Regional Office for Africa; 2004. (AFR/MAL/04/01).

67. Yangzom Y, Qian L, Shan M, La Y, Meiduo D, Hu X, et al. Outcome of hospital deliveries of women living at high altitude: a study from Lhasa in Tibet. Acta Paediatr. 2008;97(3):317-21. DOI:10.1111/j.16512227.2008.00628.x

68. Yasmin S, Osrin D, Paul E, Costello A. Neonatal mortality of low-birth-weight infants in Bangladesh. Bull World Health Organ. 2001;79(7):608-14. DOI:10.1590/S0042-96862001000700005

The authors declare no conlficts of interests. 